\title{
Menumbuhkan Minat dan Motivasi Siswa SMP terhadap Materi Fisika melalui Pembelajaran Menggunakan alat Peraga Sederhana
}

\author{
Siswanto., Yuhesti., Manurung I.F.U., Permana N., Yuniarti H., * \\ *Mahasiswa S2 Pendidikan Fisika, \\ Universitas Pendidikan Indonesia, \\ Bandung, Jawa Barat. \\ Email: sis_physics@yahoo.com
}

\begin{abstract}
Abstrak. Penelitian ini bertujuan untuk menumbuhkan minat dan motivasi siswa terhadap materi fisika melalui pembelajaran dengan menggunakan alat peraga sederhana. Penelitian ini menggunakan metode one shot case study pre experimental. Populasinya adalah seluruh siswa kelas VIII salah satu SMP di kota Bandung, sedangkan sampel penelitian diambil secara acak, yaitu sebanyak 27 siswa. Instrumen penelitian yang digunakan adalah angket dan lembar observasi. Berdasarkan hasil analisis data, diperoleh hasil bahwa penerapan alat peraga sederhana dapat menumbuhkan minat dan motivasi siswa. Siswa menjadi lebih antusias dan tertarik untuk mengikuti proses pembelajaran.
\end{abstract}

Kata kunci: alat peraga sederhana, minat, motivasi.

\section{PENDAHULUAN}

Hakikat pembelajaran IPA adalah proses dan produk. Oleh karena itu, pembelajaran IPA di sekolah tidak hanya mementingkan penguasaan fisika terhadap fakta konsep dan teori IPA (sebagai produk) tetapi yang lebih penting adalah siswa mengerti proses bagaimana fakta dan teori-teori tersebut ditemukan. Dengan kata lain siswa harus mendapat pengalaman langsung dan menemukan sendiri proses tersebut (Depdiknas, 2006).

Sesuai yang tertera dalam Standar Kompetensi dan Kompetensi Dasar Fisika SMP, pembelajaran fisika di sekolah bertujuan agar peserta didik memiliki kemampuan sebagai berikut (BSNP, 2006) (1) Membentuk sikap positif terhadap fisika dengan menyadari keteraturan dan keindahan alam serta mengagungkan kebesaran Tuhan Yang Maha Esa; (2) Mengembangkan sikap ilmiah yaitu jujur, obyektif, terbuka, ulet, kritis dan dapat bekerjasama dengan orang lain; (3) Mengembangkan pengalaman melalui percobaan agar dapat merumuskan masalah, mengajukan dan menguji hipotesis, merancang dan merakit instrumen, mengumpulkan, mengolah dan menafsirkan data, serta mengkomunikasikan secara lisan dan tertulis; (4) Mengembangkan kemampuan penalaran induktif dan deduktif dengan menggunakan konsep dan prinsip untuk mendeskripsikan berbagai peristiwa alam dan menyelesaian masalah baik secara kualitatif maupun kuantitatif; (5) Menguasai konsep dan prinsip fisika serta mempunyai keterampilan mengembangkan pengetahuan, dan sikap percaya diri sebagai bekal untuk melanjutkan pendidikan pada jenjang yang lebih tinggi serta mengembangkan ilmu pengetahuan dan teknologi.

Kemampuan-kemampuan pada poin-poin di atas oleh para guru, jarang sekali dikembangkan, padahal kompetensi tersebut nantinya harus dimiliki siswa ketika terjun langsung ke dunia kerja. Oleh karena itu, perlu kiranya seorang guru membuat proses pembelajaran yang sedapat mungkin melibatkan para pelajar dalam memecahkan masalah, mengijinkan para pelajar untuk aktif membangun dan mengatur pembelajarannya, dan dapat menjadikan pelajar yang realistis. Kegiatan pemberian pengalaman langsung terhadap siswa tersebut dapat diperoleh melalui kegiatan eksperimen maupun demonstrasi menggunakan alat peraga sederhana karena dalam upaya untuk mengajar yang baik yang meliputi (sebagian) penanganan gaya belajar siswa yang berbeda, upaya meningkatkan keaktifan partisipasi siswa dalam pembelajaran dan memberikan perubahan tempo untuk menjaga perhatian siswa serta membangkitkan rasa ingin tahunya. Demonstrasi dapat memberikan kontribusi yang berharga dalam mencapai tujuan tersebut (McFarland, 2005).

Sains mencakup pengetahuan dan cara mengetahuinya. Mengajarkan konten sains tanpa 
proses berarti mengajarkan sejarah, bukan pencarian aktif terhadap sebuah pengetahuan ilmiah (Wenning, 2009). Oleh karena itu, pertanyaan-pertanyaan arahan dikembangkan dalam rangka untuk menyempurnakan tujuan yang telah disebutkan di atas karena dengan mengajukan pertanyaan yang di desain sedemikian rupa sehingga dapat mengembangkan pemahaman konseptual, kita membuat siswa berpikir. Pertanyaan-pertanyaan tersebut dimaksudkan untuk membantu siswa menjelaskan makna, mengeksplorasi berbagai sudut pandang secara netral dan hormat serta memantau diskusi dan pemikiran mereka sendiri (VanZee et al, 2001)

Sebelum melakukan penelitian, dalam sesi wawancara terbuka dengan beberapa siswa, peneliti menyadari bahwa banyak dari mereka yang kurang meminati mata pelajaran fisika yang selama ini diikutinya. Sementara dari hasil penelitian McFarland (2005) menyebutkan bahwa banyak siswa berkomentar sangat positif tentang pembelajaran demonstrasi, seperti demonstrasi membantu pemahaman konsep dan demonstrasi membuat fisika menyenangkan.

Harapan agar proses eksperimen dan demonstrasi tersebut berlangsung menyenangkan maka perlu disediakan alat peraga yang memadai. Penggunaan alat peraga sendiri mempunyai beberapa manfaat yaitu untuk meletakkan dasar-dasar yang nyata dalam berfikir, mengurangi terjadinya verbalisme, memperbesar minat dan perhatian peserta didik untuk belajar, meletakkan dasar perkembangan belajar agar hasil belajar bertambah mantap, memberikan pengalaman yang nyata untuk dapat menumbuhkan kegiatan berusaha sendiri pada setiap peserta didik, menumbuhkan pemikiran yang teratur dan berkesinambungan, membantu tumbuhnya pemikiran dan berkembangnya kemampuan berbahasa, memberikan pengalaman yang tidak mudah diperoleh dengan cara lain serta membantu berkembangnya efisiensi dan pengalaman belajar yang lebih sempurna (McFarland, 2005).

Menurut Hartati (2010) bahwa penggunaan alat peraga dalam pembelajaran dapat meningkatkan keterampilan berfikir kritis dan hasil belajar siswa. Oleh karena itu, dalam penelitian ini digunakan suatu alat peraga untuk meningkatkan minat dan motivasi siswa, serta penguasaan konsepnya. Slameto (2010:57) menjelaskan bahwa minat adalah kecenderungan yang tetap untuk memperhatikan dan mengenang beberapa kegiatan. Kegiatan yang diminati seseorang, diperhatikan terus menerus disertai dengan rasa senang.

Berdasarkan hasil penelitian Fyan dan Maehr bahwa ada tiga faktor yang mempengaruhi prestasi belajar yaitu latar belakang keluarga, kondisi atau konteks sekolah dan motivasi (Suprijono, 2010). Motivasi belajar sebagai salah satu faktor yang mempengaruhi prestasi belajar, menurut Clayton Alderfer dalam Nashar (2004:42) adalah kecenderungan siswa dalam melakukan kegiatan belajar yang didorong oleh hasrat untuk mencapai prestasi atau hasil belajar sebaik mungkin. Oleh karena itu, dalam penelitian ini digunakan suatu alat peraga untuk menumbuhkan minat dan motivasi siswa terhadap materi fisika.

\section{METODE}

Metode penelitian ini menggunakan desain penelitian one shot case study pre experimental. Desain penelitian ini menggunakan satu kelompok yang diberikan treatment. Populasi yang digunakan adalah seluruh siswa kelas VIII di salah satu SMP di kota Bandung. Sedangkan sampel penelitian sebanyak 27 siswa. Sampel diambil secara acak.

Penelitian dilakukan dengan tujuan untuk melihat keberhasilan alat peraga sederhana dalam meningkatkan minat dan motivasi siswa. Alat peraga yang dibuat menggunakan bahan yang cukup sederhana, murah, serta mudah didapatkan. Hal ini dilakukan dengan tujuan untuk memudahkan guru yang ingin mencoba membuat alat peraga seperti ini. Metode pembelajaran yang digunakan dalam penelitian ini adalah metode demonstrasi, ceramah, dan tanya jawab. Instrumen penelitian yang digunakan adalah angket dan lembar observasi.

Angket motivasi belajar dalam penelitian ini menggunakan model motivasi ARCS yang dikembangkan oleh Keller (1987) dalam Suprijono (2010). Motivasi belajar siswa pada ARCS terdiri dari 4 indikator, yaitu Attention (Perhatian), Relevance (Relevansi), Confidende (Percaya Diri), Satisfaction (Kepuasan).

Teknik yang digunakan adalah dengan pemberian angket motivasi belajar kepada sampel penelitian. Data tentang motivasi belajar ini akan dianalisis dengan analisis deskriptif. Pemberian skor motivasi belajar diolah dalam bentuk persentase data. Selain menggunakan angket, juga digunakan lembar observasi yang diisi oleh observer.

Lembar observasi digunakan untuk mengamati aktivitas guru dan aktivitas siswa. 
Dalam lembar observasi, ada tiga kegiatan utama yang diamati, yaitu pendahuluan, kegiatan inti, dan kegiatan penutup. Masing-masing observer mengamati aktivitas guru dan siswa dari ketiga kegiatan tersebut.

Aspek yang diukur dalam penelitian ini ditinjau berdasarkan penggunakan alat peraga dalam proses pembelajaran. Alat peraga yang digunakan ada dua macam, yaitu alat peraga yang menunjukkan tekanan zat padat dan alat peraga yang menunjukkan tekanan zat cair. Alat peraga yang pertama dibuat dengan tujuan untuk menyelidiki adanya hubungan antara tekanan dengan luas bidang permukaan benda dan menyelidiki adanya hubungan antara tekanan dengan gaya yang diberikan oleh benda. Alat dan bahan yang digunakan adalah kayu yang memiliki luas penampang berbeda di kedua ujungnya, balok berukuran sama dengan massa yang berbeda, nampan dan adonan secukupnya, dengan konsentrasi sebagai berikut:

- Siapkan wadah berukuran $20 \mathrm{~cm} \mathrm{x} 15 \mathrm{~cm} \mathrm{x} 3$ cm beserta air 300 cc yang sudah dipanaskan hingga mendidih.

- Campurkan 0,25 kg tepung terigu pada air mendidih tersebut sambil diaduk-aduk hingga merata.

- Letakkan adonan tersebut di dalam wadah dan dirapikan sesuai dengan bentuk wadah.

- Letakkan sagu di atas permukaan adonan (supaya permukaan adonan tidak lengket).

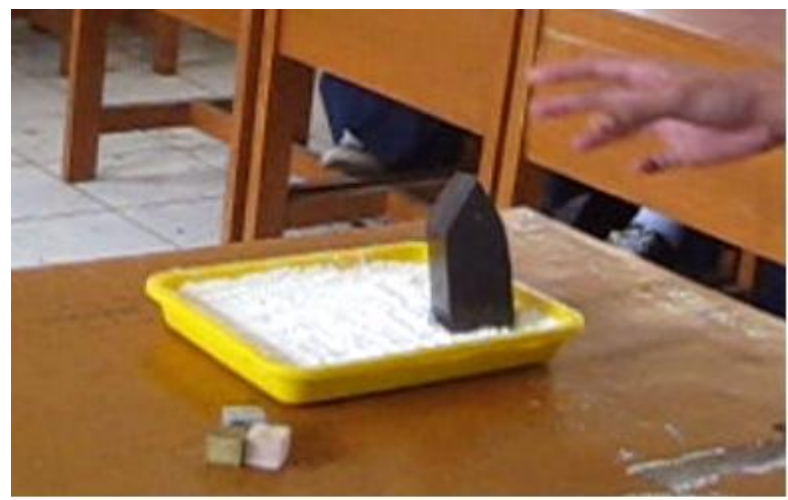

GAMBAR 1. Gambar Alat Peraga yang Menunjukkan Tekanan Zat Padat

Alat peraga yang kedua dibuat dengan tujuan untuk menemukan kaitan antara tekanan dengan kedalaman fluida dengan menggunakan alat dan bahan, yaitu botol bekas air mineral, selang secukupnya, air yang diberi pewarna, selotip, kerangka alat yang dibuat dari papan dan ember. Gambar alat peraga ditunjukkan oleh gambar 3.

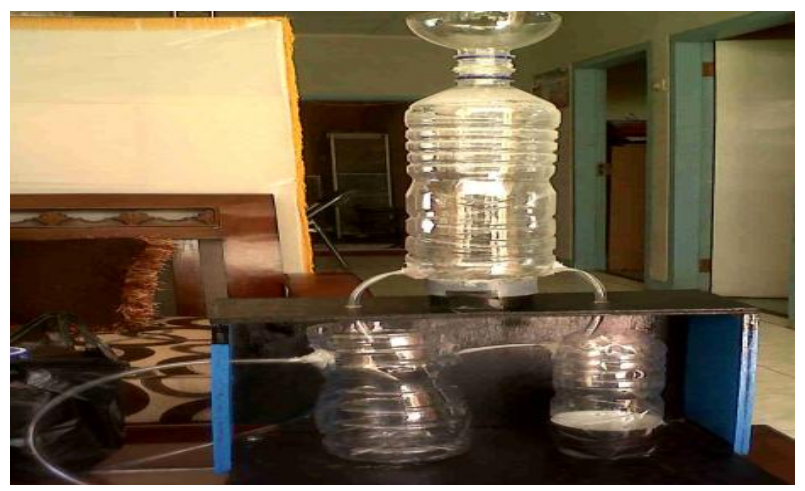

GAMBAR 2. Alat Peraga tekanan Zat Cair

\section{HASIL DAN PEMBAHASAN}

Berdasarkan hasil penelitian maka diperoleh hasil obeservasi dan hasil angket. Hasil observasi yang dilakukan oleh observer terhadap aktivitas guru dan siswa dapat dilihat pada berikut ini.

TABEL 1. Hasil Observasi Aktivitas Guru 


\begin{tabular}{llll}
\hline No & Komponen & Ya $(\%)$ & Tidak $(\%)$ \\
\hline $\mathbf{1}$ & Kegiatan Pendahuluan & 100 & 0 \\
$\mathbf{2}$ & Kegiatan Inti & 100 & 0 \\
$\mathbf{3}$ & Kegiatan Penutup & 100 & 0 \\
\hline
\end{tabular}

TABEL 2. Hasil Observasi Aktivitas Siswa

\begin{tabular}{lllll}
\hline No & Komponen & Ya (\%) & Tidak (\%) \\
\hline $\mathbf{1}$ & Kegiatan Pendahuluan & 100 & 0 \\
$\mathbf{2}$ & Kegiatan Inti & 87 & 13 \\
$\mathbf{3}$ & Kegiatan Penutup & 94 & 6 & \\
\hline \multicolumn{2}{r}{ Berdasarkan Tabel 1. secara keseluruhan } & guru & hendak & mengarahkan siswa untuk
\end{tabular}
menunjukan bahwa aktivitas guru sudah baik. Aktivitas yang dilakukan oleh guru sudah sesuai dengan sintak pembelajaran yang dibuat dalam bentuk Rencana Pelaksanaan Pembelajaran. Setelah diamati, hasil ini ternyata disebabkan karena guru melakukan persiapan dengan baik sebelum melaksanakan proses pembelajaran.

Selain itu, ketika dilaksanakan wawancara secara langsung dengan guru, ternyata guru mempelajari sintak pembelajaran yang dibuatnya sebelum melaksanakan proses pembelajaran. Guru juga menambahkan, bahwa alat peraga yang digunakan dalam pembelajaran juga membantu guru untuk memunculkan pertanyaan-pertanyaan yang dapat membangun konsep siswa. Sehingga, secara tidak langsung, alat peraga membantu guru untuk melaksanakan proses pembelajaran secara sistematis, terarah, dan terencana.

Selanjutnya, pada Tabel 2. tentang aktivitas siswa, hasil menunjukan bahwa, pada kegiatan pendahuluan aktivitas siswa sangat baik. Semua siswa mengikuti kegiatan belajar mengajar pada kegiatan pendahuluan secara sistematis. Kemudian pada aktivitas yang kedua, yaitu kegiatan inti, ternyata tidak semua siswa secara sistematis mengikuti proses pembelajaran dengan baik. Hal ini disebabkan karena ada beberapa siswa yang tidak bisa menjawab pertanyaan arahan yang diberikan oleh guru ketika melakukan demonstrasi. Selain itu, ketika menyimpulkan proses pembelajaran, ada beberapa siswa yang tidak bisa memberikan kesimpulan terhadap pembelajaran yang dilakukan. Namun, secara keseluruhan, aktivitas siswa sangat baik pada kegiatan inti. Hasil observasi menunjukan bahwa siswa antusias untuk mengikuti proses belajar mengajar. Hal ini ditunjukan dari respon siswa ketika guru mengajukan beberapa pertanyaan arahan. Hampir semua siswa menjawab pertanyaan arahan yang diajukan oleh guru. ini menunjukan bahwa siswa antusias untuk mengikuti proses belajar mengajar menggunakan alat peraga.

Kegiatan terakhir yang diamati oleh observer adalah kegiatan penutup. Pada kegiatan penutup, secara keseluruhan siswa mengikuti aktivitas-aktivitasnya dengan baik. Akan tetapi, ada beberapa siswa yang tidak bisa menyimpulkan hasil pembelajaran yang sudah dilakukan. Hal ini yang menyebabkan terdapat angka $6 \%$ untuk jawaban tidak pada lembar observasi bagian kegiatan penutup.

Instrumen selanjutnya adalah angket. Angket tersebut digunakan untuk melihat motivasi siswa terhadap proses belajar mengajar dengan alat peraga yang kami gunakan.

Setelah proses belajar mengajar selesai, dibagikan angket kepada siswa, dan menyuruh siswa untuk mengisi angket tersebut. Secara garis besar, rekapitulasi angket dapat di lihat pada Tabel 3. dan Tabel 4.

TABEL 3. Hasil Angket untuk Alat Peraga Zat Padat

\begin{tabular}{llll}
\hline No & Indikator & Ya (\%) & Tidak (\%) \\
\hline $\mathbf{1}$ & Perhatian & 89 & 11 \\
$\mathbf{2}$ & Relevansi & 78 & 22 \\
$\mathbf{3}$ & Percaya Diri & 89 & 11 \\
$\mathbf{4}$ & Kepuasan & 87 & 13 \\
\hline
\end{tabular}

TABEL 4. Hasil Angket untuk Alat Peraga Zat Padat

\begin{tabular}{llll}
\hline No & Indikator & Ya (\%) & Tidak (\%) \\
\hline $\mathbf{1}$ & Perhatian & 83 & 17 \\
$\mathbf{2}$ & Relevansi & 74 & 26 \\
$\mathbf{3}$ & Percaya Diri & 87 & 13 \\
$\mathbf{4}$ & Kepuasan & 71 & 19 \\
\hline
\end{tabular}


Berdasarkan persentase rata-rata hasil angket tersebut, terlihat bahwa alat peraga yang kami buat, baik alat peraga tekanan zat padat maupun zat cair, sudah berhasil dalam membuat siswa berminat dan termotivasi untuk belajar fisika. Oleh sebab itu, jelas bahwa alat peraga yang digunakan sangat bermanfaat bagi siswa. Secara lebih rinci, dapat dilihat pada pembahasan berikut.

Pada aspek yang pertama yaitu membahas aspek perhatian. Berdasarkan hasil angket diperoleh sebanyak 89\% (untuk alat peraga tekanan zat padat) dan $83 \%$ (untuk alat peraga tekanan zat cair) siswa yang memperhatikan pembelajaran melalui penggunaan alat peraga.

Aspek yang ke dua adalah aspek relevansi yaitu kesesuaian materi pembelajaran dengan pengalaman belajar siswa. Pada indikator ini, sebanyak $78 \%$ (untuk alat peraga tekanan zat padat) dan $74 \%$ (untuk alat peraga tekanan zat cair) siswa menganggap bahwa alat peraga yang dibuat berhasil menjelaskan fenomena-fenomena yang ditemukan dalam kehidupan sehari-hari. Menurut siswa, melalui alat peraga ini, kebingungan yang ada dalam diri siswa akan materi menjadi dapat teratasi. Lebih jauh dari itu, siswa menjadi lebih mampu mengkaitkan materi dengan fenomena yang ada dalam kehidupan sehari-hari.

Selanjutnya, komponen ketiga yang ada dalam angket ini yaitu aspek percaya diri. Sebanyak $89 \%$ siswa menjawab Ya pada angket alat peraga tekanan zat padat, dan $87 \%$ siswa menjawab Ya pada angket alat peraga tekanan zat cair. Terlihat bahwa keduanya menunjukan angka yang hampir sama. Hal ini berarti bahwa, menurut siswa penggunaan alat peraga dalam proses belajar mengajar, menjadikan siswa lebih tertarik untuk belajar tentang fisika. Sehingga, selama proses kegiatan belajar mengajar, siswa menjadi lebih percaya diri dalam pembelajaran. Selama proses belajar mengajar, siswa menjadi lebih sering bertanya, karena rasa ingin tahunya tentang akan materi yang diajarkan. Hasil ini diperkuat oleh hasil observasi yang dilakukan oleh 4 observer pada kegiatan pendahuluan dan kegiatan inti. Hasil observasi menunjukan bahwa siswa menjadi lebih percaya diri untuk mengikuti proses belajar mengajar. Selain itu, siswa menjadi tertarik untuk mengikuti proses belajar mengajar yang dilakukan oleh guru. Kepercayaan diri siswa ini ditunjukan dari banyaknya siswa yang bertanya kepada guru tentang fenomena-fenomena yang ditunjukan oleh alat peraga yang digunakan.

Kemudian, aspek yang terakhir yaitu aspek kepuasan. Berdasarkan hasil analisis terhadap angket, jelas diketahui bahwa hampir semua siswa setuju bahwa penggunaan alat peraga memberikan kepuasan terhadap diri siswa. Berdasarkan angket tersebut, siswa menjadi lebih senang dalam mengikuti kegiatan belajar mengajar. Mereka menjadi tidak bosan dalam mengikuti kegiatan belajar mengajar karena siswa diberi kesempatan untuk mengembangkan ide-idenya yang terkait dengan konsep yang dipelajari. Hasil ini diperkuat oleh hasil observasi yang dilakukan oleh observer. Berdasarkan observasi yang dilakukan, siswa menjadi lebih semangat dan pandai dalam melakukan penyimpulan terhadap proses pembelajaran yang dilakukan.

Berdasarkan hasil observasi dan angket tersebut, secara keseluruhan menunjukan respon positif dari siswa terhadap alat peraga yang digunakan dalam proses pembelajaran sehingga dapat meningkatkan minat dan motivasi siswa terhadap pembelajaran fisika.

\section{PENUTUP}

Berdasarkan hasil penelitian dan pembahasan dapat diambil kesimpulan bahwa alat peraga yang kami buat dapat digunakan pada proses belajar mengajar fisika. Alat peraga yang kami buat dapat menarik perhatian siswa untuk mengikuti proses belajar mengajar secara sistematis. Selain itu alat peraga yang kami buat juga dapat menjelaskan konsep fisika dengan benar.

Hal tersebut diperoleh berdasarkan hasil analisis lembar observasi dan angket terhadap penerapan alat peraga yang menunjukkan dimana sebanyak $78 \%$ (untuk alat peraga tekanan zat padat) dan $74 \%$ (untuk alat peraga tekanan zat cair) siswa menganggap bahwa alat peraga yang dibuat berhasil menjelaskan konsep dan sebanyak $89 \%$ (untuk alat peraga tekanan zat padat) dan $87 \%$ (untuk alat peraga tekanan zat cair) siswa menganggap bahwa alat peraga dapat meningkatkan minat dan motivasi siswa. Sehingga dapat disimpulkan bahwa penerapan alat peraga pada konsep tekanan dapat meningkatkan minat dan motivasi siswa.

\section{UCAPAN TERIMAKASIH}


Ucapan terimakasih peneliti sampaikan kepada semua pihak yang sudah membantu dalam penelitian ini, terutama guru Fisika dan Ibu Kepala SMP tempat penelitian dilakukan. Semoga hasil penelitian ini dapat bermanfaat bagi semua pihak yang membutuhkan.

\section{DAFTAR PUSTAKA}

BSNP. 2006. Panduan Penyusunan KTSP. Jakarta: Depdiknas.

Depdiknas. 2006. Kurikulum 2004 Standar Kompetensi Mata Pelajaran Fisika Sekolah Menengah Atas (SMA) dan Madrasah Aliyah (MA). Jakarta: Depdiknas.

Hartati. 2010. Pengembangan Alat Peraga Gaya Gesek Untuk Meningkatkan Keterampilan Berpikir Kritis Siswa SMA. Jurnal Pendidikan Fisika Indonesia. 6 :128-132.

McFarland, Ernie. 2005. Using Demonstrations in Teaching Physics. La Physique Au Canada. 61 (2) :8789 .

Nashar. 2004. Peranan Motivasi dan Kemampuan Awal dalam Kegiatan Pembelajaran. Jakarta: Delia Press.
Sakti, Indra., Puspasari, Yuniar Mega., Risdianto, Eko. 2012. Pengaruh Model Pembelajaran Langsung (Direct Instruction) Melalui Media Animasi Berbasis Macromedia Flash Terhadap Minat Belajar dan Pemahaman Konsep Fisika Siswa di SMA Plus Negeri 7 Kota Bengkulu. Jurnal Exacta. 10 (1) :1-10.

Slameto. 2010. Belajar dan faktor-faktor yang mempengaruhinya. Jakarta: Rineka Cipta.

Sukmadinata, N.Syaodih 2007. Metode Penelitian Pendidikan. Bandung :Rosda.

Suprijono, A. 2010. Cooperative Learning. Yogyakarta: Pustaka Pelajar.

Wenning, Carl J. 2009. Scientific Epistemology: How Scientists Know What They Know. Journal Physics Teacher Education Online. 5 (2) :315.

VanZee, Emily H. et al. 2001. Teacher Questioning During Conversation About Science. Journal of Research in Science Teaching. 38 (2) :159-190. 